\title{
Design and Implementation of Automatic Wheat Mower Based on Smart Sensor Fed by a Photovoltaic
}

\author{
Hikmet Esen, ${ }^{1}$ Abdullah Kapicioglu, ${ }^{2}$ and Onur Ozsolak ${ }^{3}$ \\ ${ }^{1}$ Department of Energy Systems Engineering, Faculty of Technology, Firat University, 23119 Elazig, Turkey \\ ${ }^{2}$ Department of Automotive Engineering, Faculty of Technology, Cumhuriyet University, 58100 Sivas, Turkey \\ ${ }^{3}$ Department of Manufacturing Engineering, Faculty of Technology, Cumhuriyet University, 58100 Sivas, Turkey \\ Correspondence should be addressed to Hikmet Esen; esenhikmet@gmail.com
}

Received 4 August 2015; Revised 19 November 2015; Accepted 30 November 2015

Academic Editor: Clito Afonso

Copyright (C) 2016 Hikmet Esen et al. This is an open access article distributed under the Creative Commons Attribution License, which permits unrestricted use, distribution, and reproduction in any medium, provided the original work is properly cited.

\begin{abstract}
The biggest problems of our time are environmental pollution and the reduction of fossil fuel resources. In recent years, photovoltaic (PV) has started to be used efficiently in order to produce electrical energy from solar energy throughout the world. In this study, a wheat mover machine taking its energy with PV technology transformation from the sun was designed supported by smart sensors. The designed vehicle was tested in two wheat fields in Sivas in Turkey. It was seen that daily average sunshine rates were not lower than $700 \mathrm{Watt} / \mathrm{m}^{2}$ during the testing dates and time. The amounts of electrical charge used to mow $5 \mathrm{~m}^{2}$ and $50 \mathrm{~m}^{2}$ areas are obtained as $500 \mathrm{mAh}$ and $3395 \mathrm{mAh}$, respectively. Also maximum power is calculated from used PV panel as 26.15 Watt during the day of the experiments. The range of solar radiation intensity is found $4.5 \mathrm{kWh} / \mathrm{m}^{2} /$ day at the studied $\mathrm{kWh}$ which was $\$ 0.140$ USD on the date of November 2015. This system is $94.5 \%$ more economic than conventional mowers over an area of $1000 \mathrm{~m}^{2}$.
\end{abstract}

\section{Introduction}

The energy resources used in the world are formed as a result of burning of fossil fuels. But burning of fossil fuels generates carbon dioxide $\left(\mathrm{CO}_{2}\right)$ and other greenhouse gases and increases density of them in the atmosphere. The accumulation of $\mathrm{CO}_{2}$, methane $\left(\mathrm{CH}_{4}\right)$, and di-nitrogen monoxide $\left(\mathrm{N}_{2} \mathrm{O}\right)$ gases in the atmosphere has increased because of human effects since 1750 and this value has reached the highest level for the last 800.000 years. Accumulation of these gases for the year 2011 has raised by $40 \%, 150 \%$, and $20 \%$, respectively, when compared to preindustrial levels and increased to 391 parts per million (ppm), 1803 parts per billion (ppb), and $324 \mathrm{ppb}$, respectively. The oceans have been acidified by absorbing about $30 \%$ of human related carbon. Average global surface temperature is predicted to increase $1.4-5.8^{\circ} \mathrm{C}$ at the end of 21th century depending on humans' fossil fuel usage [1]. Average sea level is predicted to increase $0.59 \mathrm{~m}$ depending on thermal expansion. This evaluation is presented based on the sea level between the years 1980 and 1999. Europe countries are mostly affected by these climatic changes. According to 2013 energy report, amount of carbon dioxide emission of EU countries caused by using fossil fuel was 4.174 millions of tons and $22 \%$ of this emission is generated by transportation [2]. A way of decreasing emission of greenhouse gases is to use electric vehicles instead of vehicles with internal combustion engine [3]. Using electric vehicles instead of diesel fuel powered vehicles that are commonly used in agriculture is inevitable in this change [4]. However, hybrid systems can be used with PV for these areas [5,6]. When hybrid PV-diesel-battery systems that provide power for electricity supply in hot areas were analyzed, results demonstrated that 3 hours of battery storage of a $4 \mathrm{kWp}$ PV panel with $10 \mathrm{~kW}$ diesel generator system can provide $22 \%$ of electricity supply [7]. It was reported that in agriculture $75 \%$ of chemical energy in batteries of an electrical vehicle whose energy requirement is provided by PV panel and lead acid batteries can be converted to mechanical energy [8]. In addition, usage of electric vehicle systems prevents $23 \%$ of carbon dioxide emission. However, lead acid batteries of this vehicles generate lead emission by $20.5 \%$ [9]. However, eliminating lead emission and achieving higher conversion 
rates are possible with new technology batteries [10]. Battery sourced electric vehicles were analyzed in rural agricultural areas in South Mediterranean Region. It was found that usage of these vehicles instead of entirely internal combustion vehicles will provide $63 \%$ of required energy [11]. Stand-alone hybrid PV-diesel-battery power systems were assessed in a research for the purpose of using renewable energy in rural electrification in Saudi Arabia. Results of this study show that a hybrid system that consists of $2.5 \mathrm{MWp}$ PV panel, $4.5 \mathrm{MW}$ diesel generator, and 1-hour battery storage can provide $27 \%$ of electricity required and decreases the carbon emission by $24 \%$ compared to only diesel system [12].

The biggest problems of our time are environmental pollution and the reduction of fossil fuel resources. Vehicle manufacturers are making big research and development investments in order to produce vehicles having low emission values and fuel consumption. The rapid reduction of fossil fuel resources causes fluctuation of the fuel prices. The fluctuations affect mostly the agricultural sector heavily based on use of fossil fuels. In parallel to this development, since they do not produce emission and they are limitless, renewable energy resources attract more attention and they are more widely used day by day.

In this study, discrepantly from previous study, a vehicle with renewable energy that will be used for wheat mowing was designed and tested under real environment conditions. A prototype vehicle was tested for two mowing areas. Reactive working and being programmed for different conditions were enabled for the vehicle by supporting it with smart sensor system (SSS).

\section{System Design}

When smart sensor based wheat mower with photovoltaic power source (SPWM) is set as a prototype, a carrier vehicle is required. Sizes of this carrier vehicle are $85 \mathrm{~cm} \times 64 \mathrm{~cm}$. Prototype scheme and photograph of SPWM are shown in Figures 1(a) and 1(b), respectively.

Suspension system existing in daily vehicles also exists in the vehicle power transfer system where its design provides good movement ability for the prototype vehicle. There is a flexible solar panel placed on the carrier vehicle. Since this panel is both light and bendable it is useful for mobile applications. Charge control unit was placed underside of the panel. Function of this unit is making irregular voltage and current stable. Irregular voltage and current come from the panel. The charge control unit distributes the power that will feed all the system. Lithium polymer batteries are used in order to store required power for the system. Lithium polymer batteries are developed version of lithium-ion batteries that are already being used in electric vehicles. The batteries are formed by joining of $3.7 \mathrm{~V}$ cells. The batteries used in the system are two $5100 \mathrm{mAh}$ batteries that have $11.1 \mathrm{~V}$ voltage and composed of joining of 3 cells. The reason for using a pair of batteries is allowing one of the batteries to be charged by the solar panel when the other one is functioning. The cost of batteries, inadequate space, and increment in weight of vehicle are other important factors for using only two batteries. Batteries are placed on the side of the carrier vehicle.
Since these batteries need specifically developed chargers, they must be placed on the vehicle. The electrical energy that comes from charge control unit was primarily used for charging batteries with the help of lithium polymer charger. The batteries are charged with certain current and voltage. A higher current and voltage level shortens the lifetime of the batteries. Brushless DC motor that works within the ranges of $7.4 \mathrm{~V}$ and $22.2 \mathrm{~V}$ power was used in order to provide movement power that the vehicle requires. There is a sintered neodymium magnet with $19 \mathrm{~mm}$ diameter in rotor part of this brushless motor. A $2200 \mathrm{Kv}$ brushless motor was used in our system. "Kv" mentioned here is a motor voltage constant that is used only for brushless motors and it means rotation rate of the motor per minute and per volt. This value is calculated as follows [13]:

$$
\mathrm{RPM}=\mathrm{Kv} . \mathrm{V} .
$$

Brushless motors get required energy directly from the battery and they need special equipment named electronic speed control card. Electronic speed control unit arranges the rotation speed of the motor by regulating the voltage that flows to motor. The batteries also provide energy that SSS and cutting equipment requires. SSS used in SPWM system consists of two elements that evaluate the objects around itself in terms of distance and location. This evaluation is made by two-dimensional surface scanning. The former of these parts is the laser scanner that performs surface scanning with the help of laser beams and the latter is the connection module. The connection module is electronic devices that process data coming from laser scanner and submit to the last user as output. SSS used in this study can determine the location of all objects up to $270^{\circ}$ and has the $3 \mathrm{~W}$ power consumption. While laser detector of SSS is placed in front of the vehicle, the connection module is placed to the back. The connection module which has 16 outputs is run by the help of a computer program. The program provides arrangement of many regulations from setting of the area that will be scanned to determination of sensors that will activate the output power. Power connections of cutting equipment are connected to first and second outputs of connection module. The area is determined by the help of program. Then, when the laser detectors detect an object, the connection module completes the circuit and so power is supplied for the cutting equipment.

Operating mechanism of the vehicle can be briefly explained as follows: PV that converts sun beam to electrical energy gives current and voltage which vary depending on the position of the sun and the value of solar radiation. This voltage and current are regulated by the help of charge control unit and transferred to LiPo charger. The LiPo charger uses this voltage and current in order to charge the batteries. The batteries are used to supply power for SPWM system. The power coming from batteries feeds both electronic control unit and connection module. Electronic control unit transmits the power from batteries to the motor, after regulating the motor transmits this power to the wheels with the help of differential (mechanical device). The connection module ensures operation of cutting equipment by turning on and 


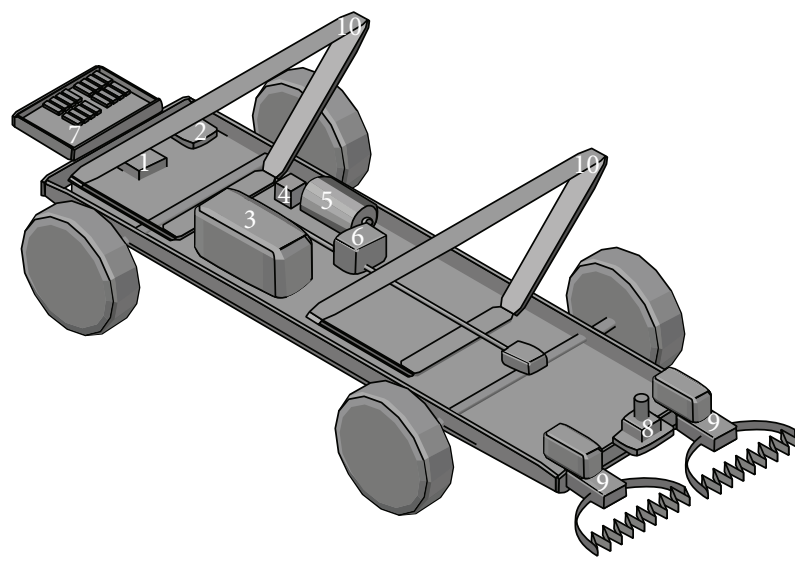

(1) Charge control unit

(2) LiPo charger

(3) Battery

(4) Electronic speed control unit

(5) DC motor

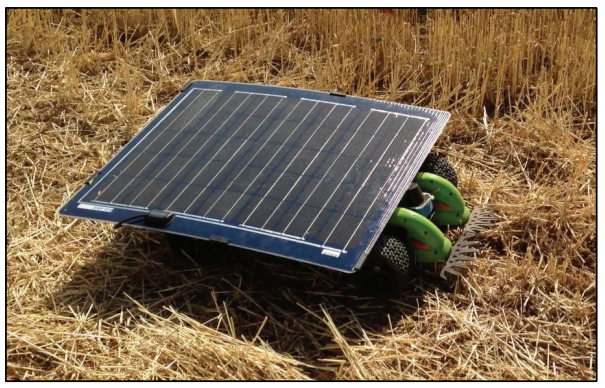
(6) Differential
(7) Connection module
(8) Smart sensor
(9) Cutting equipment
(10) Carrier feet

(a)

(b)

FIGURE 1: SPWM system, (a) prototype scheme and (b) photograph.

turning off the outputs on itself with the data from SSS. It is clear that a proper budget is necessary in order to create a valid system. Prototype for SPWM is prepared with a budget of approximately $\$ 4.560$ USD. Parts of SPWM and costs of these parts are given in Table 1.

\section{Analysis of Solar Panel}

3.1. General Characteristics of Solar Panel. It will be useful to analyze PV panel performance before analyzing general performance of the system. Therefore, characteristics of solar panel are considered under a separated heading in this study. A PV panel consists of generator solar cells, junctions, protector parts, and secondary elements. Solar cells consist of $p-n$ junctions that are aggregated on a thin silicon circuit sheet or on a semiconductor layer.

$I-V$ outcome characteristics of a solar panel in the dark are similar to exponential characteristics of a diode. When solar energy (photons) arrives in solar cell with an amount of energy greater than band gap energy of the semiconductor, collision occurs and then electron pair arises. These carriers are swept to a separated area under the influence of interior electric field of $p-n$ junctions and create a current proportional to incident radiation. This current flows to external circuit when short circuit occurs in the panel cell and it is directed to interior parallel circuit by $p-n$ junction diode when the circuit is open. Thus, characteristics of this diode shape the open circuit characteristics of the panel cell. Therefore, the simplest solar cell equivalent circuit is a parallel current source with the diode. Output acquired from current source is directly proportional to radiation on the panel cell. Solar cell is not an active element in dark. It performs as a diode. It does not generate current or voltage. However, if it is

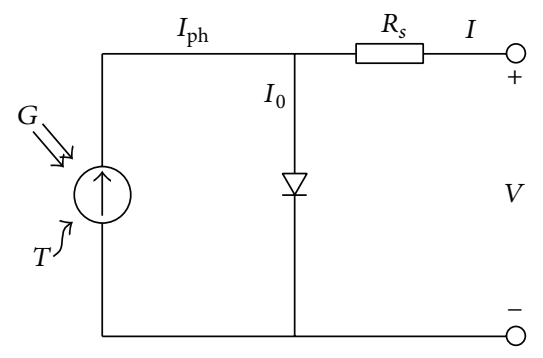

FIGURE 2: Solar cell circuit diagram of a single parallel diode. $I_{\mathrm{ph}}$ : photocurrent, $I_{0}$ : diode saturation current, $R_{\mathrm{s}}$ : serial resistance, $T$ : ambient temperature, $G$ : ambient irradiance, and $V$ : output voltage.

connected to an external source, it generates a current named as "diode current" or "dark current" $[14,15]$.

Diode determines the $I-V$ characteristics of the cell. In order to achieve the best chart curve match-up, the diode ideality factor and a single parallel diode were used. This model is the simplified version of two-diode model by Gow and Manning [16]. Solar cell circuit diagram of a single parallel diode is shown in Figure 2.

$I_{0}$ and $I_{\mathrm{ph}}$ depend on temperature. $R_{\mathrm{s}}$ is included in the circuit in order to explain the description of maximum power point and open circuit voltage better. $R_{\mathrm{s}}$ refers to interior losses caused by flow of the current. $R_{\mathrm{sh}}$ is parallel with the diode and it corresponds to the leakage current to the ground. $R_{\mathrm{sh}}$ is usually negligible and is not shown in the equivalent circuit. $R_{\mathrm{s}}=R_{\mathrm{sh}}=0$ in the ideal panel cell [16].

$I-V$ characteristics of a solar panel can be calculated by the equations given below. Middle level complexity model was used in the following equations:

$$
I_{\mathrm{ph}}=I_{d}+I \text {, }
$$


TABLE 1: The main components specification and characteristics of the system studied.

\begin{tabular}{|c|c|c|c|}
\hline System & Element & Technical specifications & Price (US\$) \\
\hline \multirow[t]{2}{*}{ Photovoltaic system } & Flexible solar panels & $\begin{array}{l}35 \text { crystal cell, max. power } 68 \mathrm{~W} \text {, average daily output } \\
272 \mathrm{Wh} / \mathrm{d} \text {, open circuit voltage } 22 \mathrm{~V} \text {, current at maximum } \\
\text { power } 3.67 \mathrm{~A} \text {, short circuit current } 3.80 \mathrm{~A} \text {, and system } \\
\text { voltage } 12 \mathrm{~V}, 800 \times 646 \times 2 \mathrm{~mm}, 5.4 \mathrm{~kg}\end{array}$ & 1025 \\
\hline & Charge control unit & $\begin{array}{l}\text { Current at maximum power } 8 \mathrm{~A} \text {, system voltage } 12 \mathrm{~V} \text {, } \\
\text { consumption value } 4 \mathrm{~mA} \text {, and dimensions } 80 \times 100 \times \\
32 \mathrm{~mm}\end{array}$ & 58 \\
\hline \multirow{2}{*}{ Carrier system } & Carrier vehicle & $\begin{array}{l}2200 \mathrm{Kv} \text { brushless motor, max } 25.2 \mathrm{~V} \text {, ESC } 25.2 \mathrm{~V} 120 \mathrm{~A} \text {, } \\
\text { Servo Motor (6 Volt } 12 \mathrm{~kg} \text { torque })(770 \times 470 \times 290 \mathrm{~mm})\end{array}$ & 1490 \\
\hline & Remote control & $\begin{array}{l}2.4 \mathrm{GHz}, 4 \text {-channel S-FHSS } \\
\text { Computer radio system }\end{array}$ & 382 \\
\hline \multirow[b]{2}{*}{ Storage system } & Lithium polymer battery & $12.6 \mathrm{~V}, 5100 \mathrm{mAh}, 40^{\circ} \mathrm{C}, 56.61 \mathrm{Wh}$. & $\begin{array}{c}372 \\
(2 \mathrm{pcs})\end{array}$ \\
\hline & Charger & $\begin{array}{l}\text { Input voltage: } 11-18 \mathrm{~V} \text { DC charge power: } \max .50 \mathrm{~W} \text {, } \\
\text { discharge power: max. } 5 \mathrm{~W} \text {, charge current range: } \\
0.1-5.0 \mathrm{~A} \text {, discharge current range: } 0.1-1.0 \mathrm{~A} \text {, current drain } \\
\text { for balancing LiPo: } 300 \mathrm{mAh} / \text { cell, LiPo/LiIo/LiFe battery } \\
\text { cell count: } 1-6 \text { series, dimension: } \\
135 \times 125 \times 34 \mathrm{~mm} \text { and weight: } 800 \mathrm{~g}\end{array}$ & 93 \\
\hline \multirow[t]{2}{*}{ Smart sensor system } & Sensor & $\begin{array}{l}\text { Light source: infrared }(850 \mathrm{~nm}) \text {, laser class: } 1 \text { (EN } 60825-1 \\
(2007-10)) \text {, eye-safe, field of view: } 270^{\circ} \text {, scanning } \\
\text { frequency: } 15 \mathrm{~Hz} \text {, angular resolution: } 1^{\circ} \text {, and operating } \\
\text { range: } 0.05 \mathrm{~m} . .4 \mathrm{~m} \\
\text { Max. range with } 10 \% \text { reflectivity: } 2 \mathrm{~m} \\
\text { Operating voltage: } 10 \mathrm{~V} \text { DC. . } 28 \mathrm{~V} \mathrm{DC} \text {, power } \\
\text { consumption: type } 3 \mathrm{~W} \text {, without output load }\end{array}$ & 884 \\
\hline & Connection module & $\begin{array}{l}\text { USB interface, input voltage: } 10 \text { to } 30 \mathrm{~V} \mathrm{DC} \text {, power } \\
\text { consumption } 1 \mathrm{~W} \text {, and "touch and teach" }\end{array}$ & 93 \\
\hline Mowing system & Cutting equipment & $\begin{array}{l}\text { Cutting edge width } 160 \mathrm{~mm} \\
\text { Operating voltage: } 10.8 \mathrm{~V} \text {, rotation speed } 1100 \mathrm{rpm} \text {, } \\
\text { Dimension } 330 \times 172 \times 135 \mathrm{~mm}, 1.1 \mathrm{~kg}\end{array}$ & $\begin{array}{c}161 \\
(2 \mathrm{pcs})\end{array}$ \\
\hline Total & & & 4558 \\
\hline
\end{tabular}

TABLE 2: Ideality factor of several PV types.

\begin{tabular}{lc}
\hline PV type & $n$ \\
\hline Monocrystalline silicon & 1.2 \\
Polycrystalline silicon & 1.3 \\
Cadmium telluride & 1.5 \\
Gallium arsenide & 1.3 \\
Amorphous silicon & 1.8 \\
\hline
\end{tabular}

$$
\begin{aligned}
& I_{d}=I_{0}\left(e^{q\left(V+\mathrm{IR}_{s}\right) / n k T}-1\right), \\
& I=I_{\mathrm{ph}}-I_{0}\left(e^{q\left(V+\mathrm{IR}_{s}\right) / n k T}-1\right),
\end{aligned}
$$

where $I_{d}$ is short explaining of the $I_{0}\left(e^{q\left(V+\mathrm{IR}_{s}\right) / n k T}-1\right), q$ is elementary charge $\left(1.602 \times 10^{-19} \mathrm{C}\right), k$ is Boltzman constant $\left(1.381 \times 10^{-23} \mathrm{~J} / \mathrm{K}\right)$, and $n$ is diode ideality factor; it depends on the PV technology as it is shown in Table 2.
Equations (2), (3), and (4) are not enough to draw the $I-V$ curve: $I_{\mathrm{ph}}, V_{\mathrm{oc}}$, and $I_{0}$ are required to complete the model:

$$
\begin{aligned}
I_{\mathrm{ph}} & =I_{\mathrm{ph}}\left\langle T_{\text {ref }}\right\rangle+K_{0}\left(T-T_{\text {ref }}\right), \\
I_{\mathrm{ph}}\left\langle T_{\text {ref }}\right\rangle & =I_{\mathrm{sc}}\left\langle T_{\text {ref }}\right\rangle \frac{G}{G_{\text {ref }}}, \\
I_{0}\left\langle T_{\text {ref }}\right\rangle & =\frac{I_{\text {sc }}\left\langle T_{\text {ref }}\right\rangle}{\left(e^{\left.q V_{\text {oc }}\left\langle T_{\text {ref }}\right\rangle / n k T_{\text {ref }}-1\right)},\right.} \\
I_{0} & =I_{0}\left\langle T_{\text {ref }}\right\rangle\left(\frac{T}{T_{\text {ref }}}\right)^{3 / n} e^{q V_{g}\left(T_{\text {ref }}\right) / n k\left(1 / T-1 / T_{\text {ref }}\right)},
\end{aligned}
$$

where Ref. identifies the standard test conditions $\left(T_{\text {ref }}=\right.$ $\left.25^{\circ} \mathrm{C}, G_{\text {ref }}=1000 \mathrm{~W} / \mathrm{m}^{2}\right), K_{0}$ is temperature coefficient of the current, $I_{\mathrm{sc}}$ is short circuit current, and $V_{\mathrm{oc}}$ is open circuit voltage. 


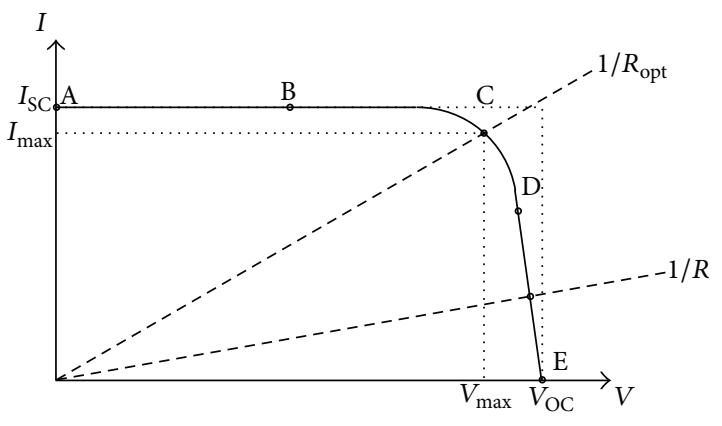

FIgURE 3: Specific $I-V$ characteristics of solar cell.

We should know the values of $R_{\mathrm{s}}$ because it has a considerable effect on $I-V$ characteristic curves:

$$
\begin{aligned}
R_{s} & =-\frac{d V}{d I_{V_{\mathrm{oc}}}}-\frac{1}{X_{v}} \\
X_{V} & =I_{O}\left(T_{\text {ref }}\right) \frac{q}{n k T_{\text {ref }}} e^{q V_{\text {oc }}\left(T_{\text {ref }}\right) / n k T_{\text {ref }}} .
\end{aligned}
$$

Constants in these equations can be determined by analyzing $I-V$ curve charts which are measured or published in product catalogues of PV system manufacturers.

Specific $I-V$ characteristics of solar cell for a determined $G$ and $T$ are shown in Figure 3. Characteristic of a resistive charge is a linear line within the scope of $I / V=1 / R$. Also it should be mentioned that power delivered to this charge is based only on the resistance value [15].

However, panel has an effect on A-B part of the curve chart if $R$ value is low. Cell acts as a constant current source here and it is almost equal to short circuit current. On the other hand, panel has an effect on D-E part of the curve chart if $R$ value is high. Cell acts as a constant voltage source here and it is almost equal to open circuit voltage [17].

A real solar cell can be characterized by following basic parameters shown in Figure 3.

For short circuit current, $I_{\mathrm{sc}}=I_{\mathrm{ph}}$. This is the maximum current value produced by the cell. It can be produced by short circuit conditions $V=0$.

Open circuit voltage corresponds to diminished voltage in the diode ( $p-n$ junction) when it is crossed by $I_{\mathrm{ph}}$. In other words, it represents the cell voltage in dark, when the produced voltage is $I=0$,

Maximum power point is the operating point $\mathrm{C}$ in Figure 3. This is the consumed power when the resistive charge level is maximum: $P_{\max }=V_{\max } \cdot I_{\max }$.

Maximum efficiency is the ratio between maximum power and incident light:

$$
\eta=\frac{P_{\max }}{P_{\text {in }}}=\frac{I_{\max } V_{\max }}{A G} .
$$

$A$ is the panel cell area. The efficiency of our system was calculated and result was found as $19.92 \%$.
Fill factor is the ratio between maximum power delivered to charge and output of $I_{\mathrm{sc}}$ and $V_{\mathrm{oc}}$ :

$$
\mathrm{FF}=\frac{P_{\max }}{V_{\mathrm{oc}} I_{\mathrm{sc}}}=\frac{I_{\mathrm{max}} V_{\mathrm{max}}}{V_{\mathrm{oc}} I_{\mathrm{sc}}} .
$$

Fill factor is a measure of actual $I-V$ characteristics. This value is higher than 0.7 for the cells that can be accepted as good. The fill factor of the panel used in our system is 0.81 . Fill factor decreases as cell temperature increases.

While $I_{\mathrm{sc}}$ is a linear function of ambient radiation, $V_{\mathrm{oc}}$ shows a logarithmic increase with ambient radiation. Dominant effect caused by the increase in cell temperature is the linear decrease of $V_{\text {oc }}$. Thus, the cell functions less efficiently. $I_{\mathrm{sc}}$ shows only a slight increase with cell temperature.

The effects of the $G$ and cell temperature on characteristics of the cell can be found by equations. $I_{\mathrm{ph}}(A)$ is directly proportional to solar radiation. When solar cell is short circuited, a negligible current arises in the diode. Thus, a proportional constant short circuit current $I_{\mathrm{sc}}$ related to calculated radiation value (6) is set. Generally panel data are calculated under $G_{\text {ref }}$ on the conditions where sea level, humidity, and aerosol particle density are at average levels. PV cell performance does not change significantly in terms of full sunniness and cloudiness. With the received solar energy, power output shows approximately a linear decrease; however, efficiency rate approximately coincides with the preferred values.

The relationship between photocurrent and temperature is linear (5) and this result is obtained by recording the temperature changes caused by photocurrent differences. The relationship between terminal voltage and current of the cell is given by Shockley equation when there is no radiation on panel cell. When the cell is open circuited and there is radiation on it, current occurs entirely in the diode. $I-V$ curve is shifted from the origin by the current produced by radiation (4). Saturation current value $I_{0}$ in the temperature of $25^{\circ} \mathrm{C}$ is calculated by open circuit voltage and short circuit current in that temperature (7). Ideality factor is offered as 1.2-1.3 under normal operation conditions and then it is stated that it can be used as initial until a more accurate value is calculated by curve chart simulation. $I_{0}$ has a complicated relationship with temperature; however, it does not include any variables that require evaluation (8). $R_{\mathrm{s}}$ on the panel does not have a strong influence on tendency at the $V=V_{\text {oc }}$ point of the $I-V$ curve chart. Equations (9) are found by derivation of (4) and evaluation at the $V=V_{\text {oc }}$ point and by making reformation in terms of $R_{\mathrm{s}}$ [15].

3.2. MATLAB Model of the Solar Panel. The solar panel used in our system is $\mathrm{S} 225 \mathrm{M} 36$ which provides a maximum power of $68 \mathrm{~W}$ and has 35 polycrystalline silicon cells. Catalogue data of solar panel are given in Table 3.

Model of solar panel is calculated by using a MATLAB software program. Parameters of the model are assessed during the implementation by using equations listed in the previous section. The program calculates the current by using electrical parameters $\left(I_{\mathrm{sc}}, V_{\mathrm{oc}}\right)$ specific to this program, voltage, radiation, and temperature variables. In addition 
TABLE 3: Catalogue data of solar panel.

\begin{tabular}{lcc}
\hline Parameter & Symbol & Value \\
\hline Maximum power & $P_{\mathrm{M}}$ & $68 \mathrm{~W}$ \\
Voltage at maximum power & $V_{\mathrm{M}}$ & $19 \mathrm{~V}$ \\
Open circuit voltage & $V_{\mathrm{oc}}$ & $22.6 \mathrm{~V}$ \\
Current at maximum power & $I_{\mathrm{M}}$ & $3.67 \mathrm{~A}$ \\
Short circuit current & $I_{\mathrm{sc}}$ & $3.8 \mathrm{~A}$ \\
Number of cells & $N_{\mathrm{P}}$ & 35 \\
\hline
\end{tabular}

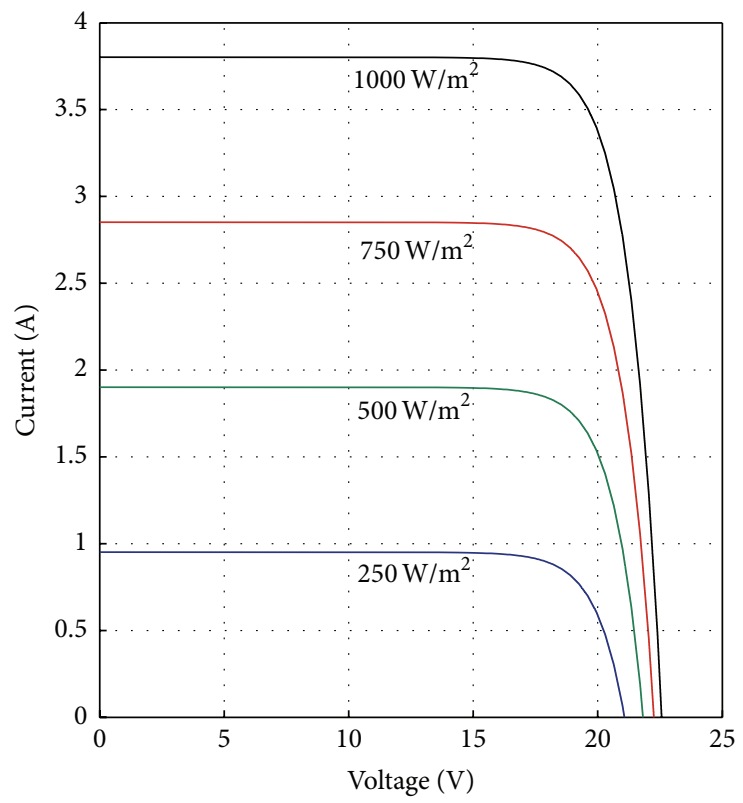

FIGURE 4: MATLAB model $I-V$ curves for various irradiation levels.

to this, this program takes series resistors of the model into account as well. This resistance creates a solution for current (4). Newton-Raphson method is used in this program because this method provides a much more quick calculation of both positive and negative currents. Output of MATLAB function is shown in Figures 4 and 5. Figure 4 shows the output for varying levels of radiation and Figure 5 shows the output for varying temperature.

The values for variable temperatures are shown on the curve chart in Figure 5. These lines are taken directly from the manufacturer's published curves and show excellent correspondence to the model. It is shown in the curve charts of S225M36 that $I_{\text {ph }}$ varies from 3.80 A to $4.00 \mathrm{~A}(5 \%)$ by the increase in $T$ from $25^{\circ} \mathrm{C}$ to $75^{\circ} \mathrm{C}$. Figure 6 shows the power voltage tendencies for some temperature levels.

Values observed in the model results show the power, current, and voltage values that can be produced by the panel at different levels of temperature. These results coincide with that obtained from the literature and PV producer.

\section{Experimental Study and Findings}

Experiments are performed during sunny day time between the dates 27.07.2013 and 03.08.2013. Experiments are analyzed

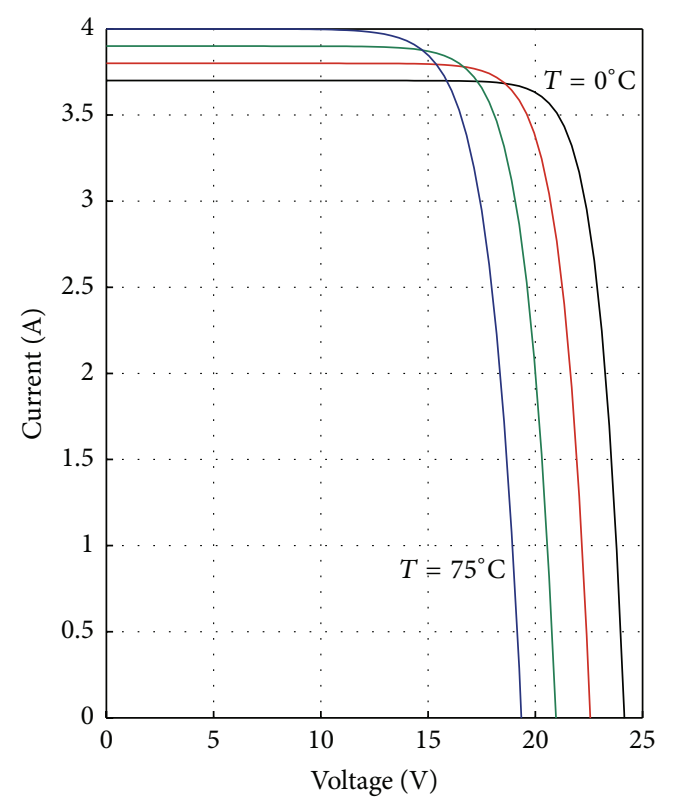

Figure 5: MATLAB model $I$ - $V$ curves for various temperatures.

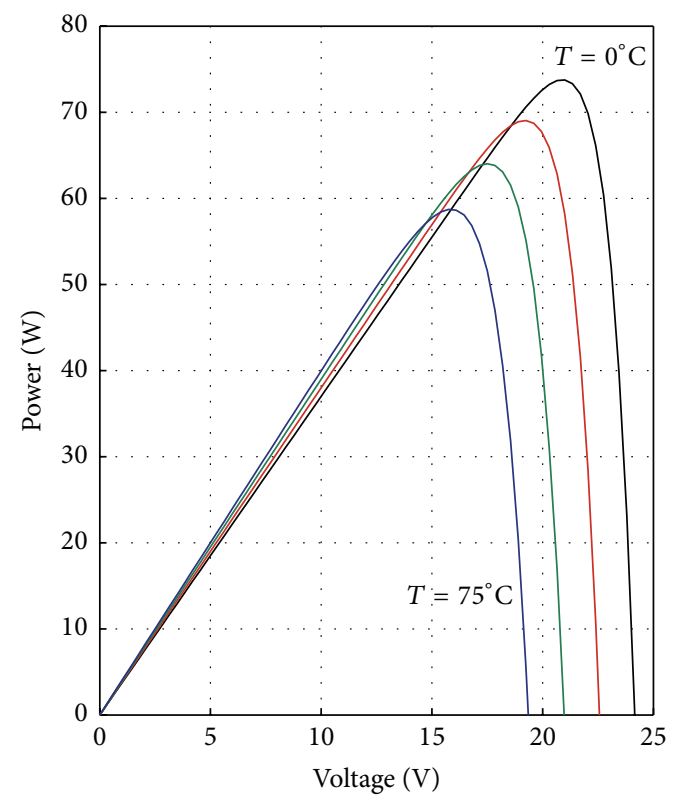

Figure 6: MATLAB model $P-V$ curves for various temperatures.

under three headings which are PV data experiments, field experiments, and vehicle (mower) experiments. In this study, PV system consists of two parts that are solar cell and charge control unit. Solar cell converts the radiation from the sun to electrical energy and charge control unit regulates and transmits this electrical energy to the system. Current and voltage values provided by the panel were measured at intervals of 15 minutes on sunny days. Fill factors of PV charged batteries were measured in terms of $\mathrm{mAh}$ with regular intervals. The device applied in the study is able to show the given current value and battery current value separately for each cell. Daily radiation values were measured by solarimeter during 


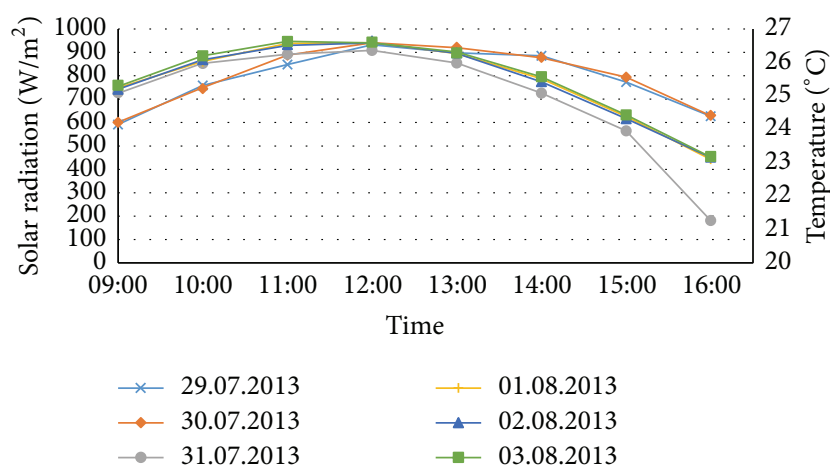

FIGURE 7: Hourly solar radiation and temperature changes in the experimental period.

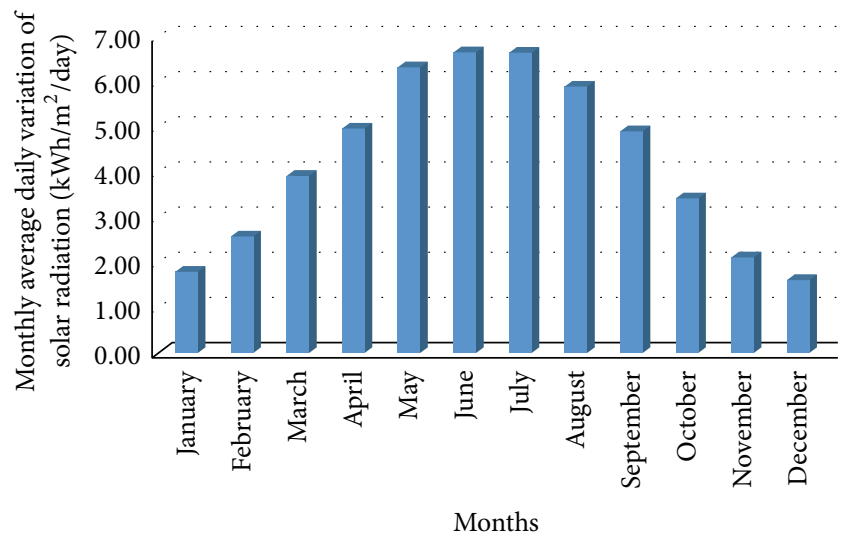

FIGURE 8: Monthly average daily variation of solar radiation over the year.

the experiments. A program that renders the data delivered from the SSS is used for field measurements. Field measurement values, locations of objects, and different scanning fields can be achieved by means of this program.

The most important factor during the PV based experiments is undoubtedly the sunshine rate. The changes which occurred during the experiment period of 6 days are included in Figure 7. It was seen that daily average sunshine rates were not lower than $700 \mathrm{Watt} / \mathrm{m}^{2}$ during the experimentation dates and time. This value provides a radiation value enough to charge the batteries.

The province of Sivas located in Central Anatolia Region in Turkey has $6.5 \mathrm{kWh} / \mathrm{m}^{2} /$ day monthly average daily variation of solar radiation over the year as pointed out in Figure 8.

Uncharged voltage value of the system differs between 20 and $22 \mathrm{~V}$ depending on the solar radiation value. This value falls to $15 \mathrm{~V}$ when the charge is connected to the system. Output voltage shows variations depending on the temperature and on the radiation rates of the panel. Nonetheless, there is not any fluctuation on the voltage which is used to charge polymer batteries by charge control unit due to the panel provided output power is greater than required power (see Table 4).

Time related panel data values are given in Table 4 and descriptions of parameters are as follow: $T_{\text {avr }}\left({ }^{\circ} \mathrm{C}\right)$ refers to
TABLE 4: Time related environment and panel data value.

\begin{tabular}{cccccc}
\hline Time & $T_{\text {avr }}\left({ }^{\circ} \mathrm{C}\right)$ & $G_{\text {avr }}\left(\mathrm{W} / \mathrm{m}^{2}\right)$ & $V_{\text {po }}$ & $V_{\text {co }}$ & $I_{\text {cd }}$ \\
\hline $09: 00$ & 23.9 & 592 & 14.6 & 11.5 & 1.3 \\
$10: 00$ & 24.1 & 759 & 14.7 & 11.5 & 1.8 \\
$11: 00$ & 24.2 & 848 & 15 & 11.5 & 1.9 \\
$12: 00$ & 25.1 & 932 & 15.4 & 11.5 & 2.1 \\
$13: 00$ & 24.1 & 899 & 15.2 & 11.5 & 1.8 \\
$14: 00$ & 23.5 & 886 & 15.2 & 11.5 & 1.7 \\
$15: 00$ & 22.9 & 773 & 15 & 11.5 & 1.7 \\
$16: 00$ & 20.3 & 627 & 14.6 & 11.5 & 1.3 \\
\hline
\end{tabular}

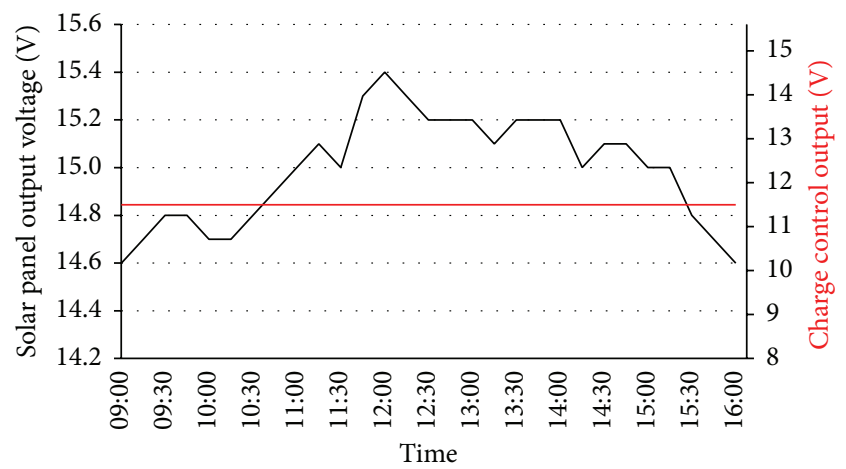

FIGURE 9: Change in solar panel and charge control output voltages during charge of battery.

hourly average temperature; $G_{\text {avr }}$ refers to hourly average radiation values provided by the panel; $V_{\text {po }}$ refers to panel output voltage; $V_{\text {co }}$ refers to charge control unit output voltage; $I_{c d}$ refers to current drawn from the panel during charging.

Voltage values that vary depending on 15 -minute periods when LiPo batteries are connected to the circuit are shown in Figure 9.

In the experiments conducted between the hours 09:00 and 16:00 on the date shown in Figure 9, it was seen that the PV provided energy is enough to charge the battery. Observations from the experiments show that output voltage values of the PV system vary between $14.6 \mathrm{~V}$ and $15.4 \mathrm{~V}$. Afterwards, voltage values were read on charge control unit and it was seen that the voltage of charge control unit is reduced to $11.5 \mathrm{~V}$ and this value is enough to meet the required voltage for the system. It was also seen that PV system cannot satisfy the special charge conditions of LiPo batteries except for the measurement time periods (solar radiation is insufficient before 09:00 and after 16:00).

Besides voltage rating during charging of the batteries, the current transmitted to the batteries is also of high importance. Charging the batteries depends on the current value. Current values obtained from $\mathrm{PV}$ by batteries with charge control unit are shown in Figure 10.

If the value of current coming from the solar panel is higher than 2.1 A when the batteries are charged, the charger warns about the insufficient power; thus, maximum charge current is determined as $2.1 \mathrm{~A}$. Lower current value affects 


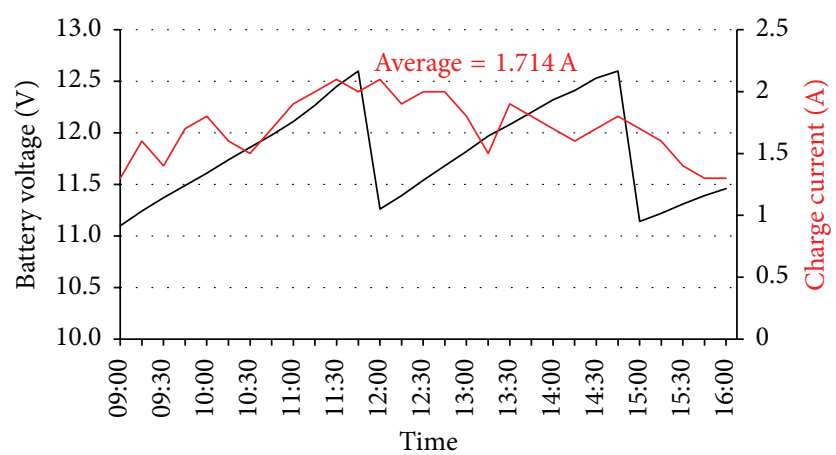

FIGURE 10: Change in voltage and charge flow values during charge of batteries.

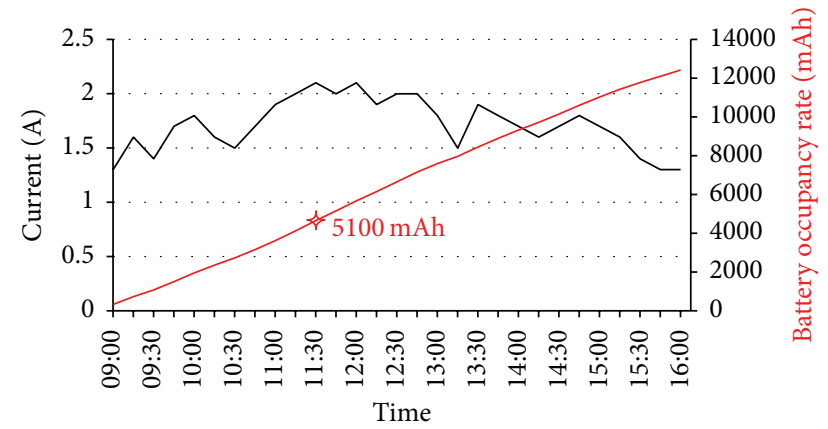

FIGURE 11: Change in input and current values during charge of batteries.

the time required to charge the batteries and battery cycle rate. Battery cycle rate, mentioned here, means recharging the battery after being used during the day. The longer the battery cycle is the longer the operating time of the vehicle is. For LiPo batteries, one of the parameters indicating that the battery is fully charged is the voltage rate of each cell. As mentioned before, nominal voltage rate of LiPo batteries used in the experiment is $3.7 \mathrm{~V}$ for each cell and in total $11.1 \mathrm{~V}$ for 3 cells. Maximum fill factor of one cell is determined as $4.2 \mathrm{~V}$ by the manufacturer. It was observed that in the experiments performed on 27.07.2013, the battery that began to be charged at 09:00 was fully charged at 11.38 then the second battery began to be charged. During the experiments, charge duration of a battery is determined as 2 hours and 40 minutes. Input current values that are transmitted to batteries from PV via charge control unit between the hours 09:00 and 16:00 and changes in current values that charge the battery are given in Figure 11.

Instant power rates during the charge of the battery are calculated by using current and voltage values measured in the experiments. Equation used for this calculation is shown below [13]:

$$
P(t)=V(t) \cdot I(t)
$$

where $P(t)$ is instant power (W), $V(t)$ is voltage $(\mathrm{V})$, and $I(t)$ is current $(\mathrm{A})$.

Instantaneous power changes during charge of batteries are given in Figure 12. On the days of experiment maximum

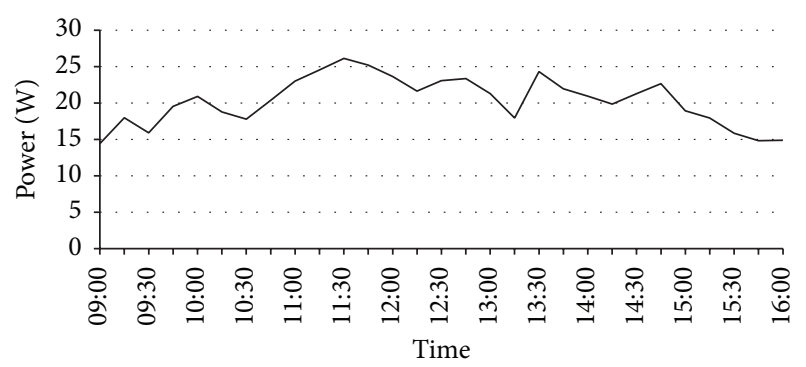

FIGURE 12: Instantaneous power change during charge of battery.

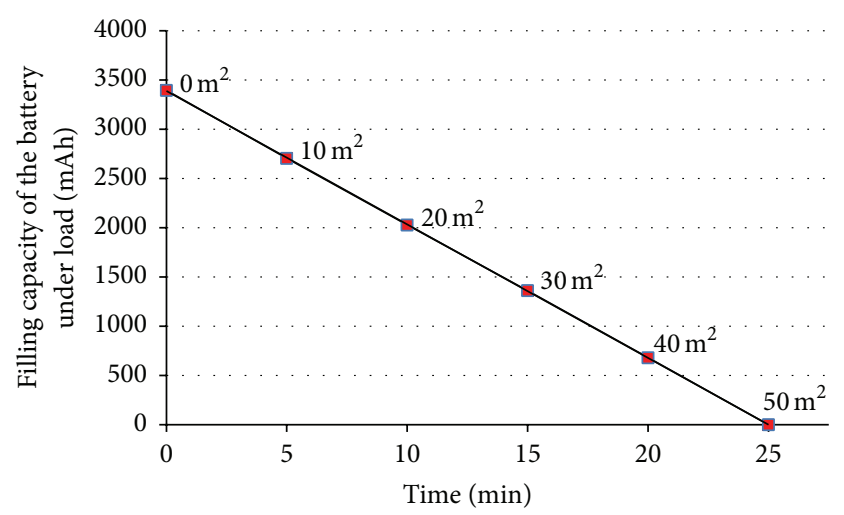

FIGURE 13: Time related change graph of field to be mowed and consumed electrical charge.

power coming from the flexible PV is $26.15 \mathrm{~W}$ and daily average power rate is calculated as $20.31 \mathrm{~W}$.

The energy stored by help of panel and batteries enables the vehicle to mow on the experiment field. One of the fields where mowing was performed was a field with an area of $5 \mathrm{~m}^{2}$ where there were wheatears and the other was a field with an area of $50 \mathrm{~m}^{2}$ where there were earless wheat stems.

Prototype has performed mowing activity successfully during the experiments. It was observed that overall performance during the mowing is related to the surface of the area to be mowed. Vehicle that had some difficulties mowing inclined areas had no difficulty in mowing ears of grains on plain areas.

Digital remote control is used in order to direct the movements of the vehicle. Many parameters, such as vehicle acceleration, turning circle, and maximum speed, can be controlled with the help of this digital control. Approximately $500 \mathrm{mAh}$ of electrical charge has been spent over the course of mowing experiments for an area of $5 \mathrm{~m}^{2}$ and this value is $3395 \mathrm{mAh}$ for an area of $50 \mathrm{~m}^{2}$. The graph which shows time based change in the usage of electrical charge and mowed area is shown in Figure 13.

While all these activities are being implemented the vehicle scans the surface. The vehicle can be programmed in many different ways and it is programmed to start operation as soon as wheat is detected. The scanning area where the vehicle operates is divided into three separate parts. The vehicle starts operating when wheat stems are detected where they are closest to the sensor. This closest area is illustrated 


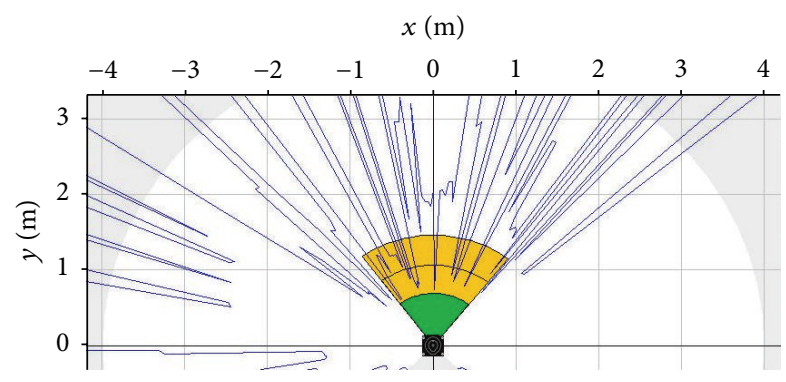

FIGURE 14: The most proper area for SPWM system detected by sensor.

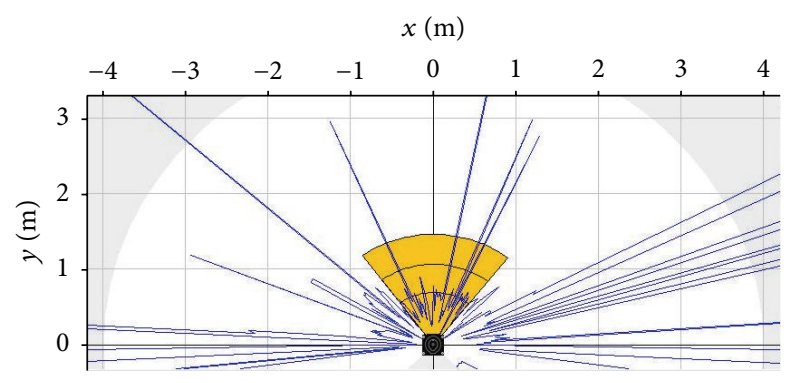

FIGURE 15: View of beginning to wheat mowing process.

in green in Figure 14. Area scanning image before the system operation is given in Figure 14. At this stage, SSS scans the area but does not operate. System begins to operate when the scanning imagery in Figure 15 is obtained. Here, the programmed scanning area is seen in the shape of 1/6-circle. This shape of circle allows us to approach to the vehicle on both right and left sides and provides safe implementation of control and maintenance activities for the vehicle.

Experimental areas where the mowing process are performed present successful results when the sizes of these areas are taken into consideration.

When the vehicle designed in this research is compared with a mower that has $127 \mathrm{~cm}$ cutting width and $7.5 \mathrm{~kW}$ single cylinder diesel engine and has a sale price of $\$ 10.250$ USD, the results are as follows. Catalogue values of the vehicle show that the required amount of fuel to mow an area of $1000 \mathrm{~m}^{2}$ is $1.4 \mathrm{~L}$. Price of fuel per unit was $\$ 1.56$ USD on the date of November 2015 (Turkey). When this unit price is taken into account, mowing an area of $1000 \mathrm{~m}^{2}$ costs $\$ 2.18$ USD in total. The same calculation is done for our designed vehicle: $3395 \mathrm{mAh}$ for $50 \mathrm{~m}^{2} ; 3395 \mathrm{mAh} \times 20=67900 \mathrm{mAh}$, and this value is approximately equal to $68 \mathrm{Ah}\left(\right.$ for $\left.1000 \mathrm{~m}^{2}\right)$. By the help of the equation $P=I V ; 68 \times 14.9=1013$ Watts $=1 \mathrm{~kW}$ electrical energy is spent for mowing the area of $1000 \mathrm{~m}^{2}$. Unit price of $\mathrm{kWh}$ was $\$ 0.140$ USD on the date November 2015. On the other hand, the cost of mowing $1000 \mathrm{~m}^{2}$ area by using our wheat mower is $\$ 0.140$ USD. Our system saves money by $90 \%$ when compared to conventional mowers over an area of $1000 \mathrm{~m}^{2}$ for Turkey economic condition of November 2015. However sizes, battery capacities, and PV power of designed vehicle are relatively smaller due to the fact that it is a prototype. Therefore, its daily storage capacity is approximately $12 \mathrm{Ah}$ as shown in Figure 10. According to these values, mowing activity lasts approximately 6 days.

\section{Conclusions}

In this study, applicability of solar energy which is available in Turkey abundantly to agriculture has been investigated. In recent years, PV has started to be used efficiently in order to produce electrical energy from solar energy throughout the world. PV and battery prices corresponding to the cost of the manufacturing, module efficiency, and market features vary worldwide. Besides, an estimate for the global price of basic $\mathrm{PV}$ modules in 2008 was $\$ 4 / \mathrm{W}$ USD and this price reduces to $1.05 / \mathrm{W}$ in 2015 by declining $75 \%$ over the five years. Wheat mower which runs on PV has been designed. PV used in this study is modeled in MATLAB. Returns necessary for the system are provided by equipping the wheat mower prototype with sensor system. Results and suggestions of this study are listed below:

(i) Effective mowing is performed by this system and there is no other system similar to this one.

(ii) Operating time of prototype vehicle is increased by $30 \%$ with the help of PV.

(iii) The amounts of electrical charge used to mow $5 \mathrm{~m}^{2}$ and $50 \mathrm{~m}^{2}$ areas are obtained as $500 \mathrm{mAh}$ and $3395 \mathrm{mAh}$, respectively.

(iv) Operating time for an area of $75 \mathrm{~m}^{2}$ is calculated as 37 minutes with a battery used in the system at a constant level of power.

(v) Maximum power is calculated from used PV panel as 26.15 Watt during the day of the experiments.

(vi) It is proved that laser scanner systems can be used in any field.

(vii) This system is $94.5 \%$ more economic than conventional mowers over an area of $1000 \mathrm{~m}^{2}$. However, sizes, battery capacities, and PV power of designed vehicle are relatively smaller due to being a prototype.

(viii) It is observed that flexible PVs are proper to be used on agricultural fields but better studies can be achieved by increasing output power levels.

\section{Conflict of Interests}

The authors declare that there is no conflict of interests regarding the publication of this paper.

\section{Acknowledgment}

The authors gratefully acknowledge the financial support from the Scientific Research Projects Administration Unit of Firat University for this study performed under projects with Grant no. TEKF 2013/13.07. 


\section{References}

[1] Climate Change Synthesis Report, Contribution of Working Groups I, II and III to the Fourth Assessment Report of the Intergovernmental Panel on Climate Change, IPCC, Geneva, Switzerland, 2007.

[2] European Commission, EU Energy and Transport FiguresStatistical Pocketbook, European Commission, Brussels, Belgium, 2013.

[3] SET-Plan, Strategic Energy Technology Plan, 2014, http://ec .europa.eu/energy/technology/set_plan/set_plan_en.htm.

[4] M. Farhoodnea, A. Mohamed, H. Shareef, and H. Zayandehroodi, "Power quality impacts of high-penetration electric vehicle stations and renewable energy-based generators on power distribution systems," Measurement, vol. 46, no. 8, pp. 2423-2434, 2013.

[5] B. A. Stout and M. McKiernan, "New technology-energy implications," in Energy in World Agriculture. Energy in Farm Production, R. C. Fluck, Ed., vol. 16, chapter 11, pp. 131-171, Elsevier, Amsterdam, The Netherlands, 1992.

[6] K. D. Edwards, R. M. Wagner, T. E. Briggs, and T. J. Theiss, "Defining engine efficiency limits," in Proceedings of the 17th Directions in Engine-Efficiency and Emissions Research (DEER '11), Detroit, Mich, USA, 2011.

[7] S. M. Shaahid and M. A. Elhadidy, "Economic analysis of hybrid photovoltaic-diesel-battery power systems for residential loads in hot regions-a step to clean future," Renewable \& Sustainable Energy Reviews, vol. 12, no. 2, pp. 488-503, 2008.

[8] H. Mousazadeh, A. Keyhani, H. Mobli, U. Bardi, G. Lombardi, and T. el Asmar, "Environmental assessment of RAMseS multipurpose electric vehicle compared to a conventional combustion engine vehicle," Journal of Cleaner Production, vol. 17, no. 9, pp. 781-790, 2009.

[9] H. Mousazadeh, A. Keyhani, H. Mobli, U. Bardi, G. Lombardi, and T. el Asmar, "Technical and economical assessment of a multipurpose electric vehicle for farmers," Journal of Cleaner Production, vol. 17, no. 17, pp. 1556-1562, 2009.

[10] G. Albright, J. Edie, and S. Al-Hallaj, A Comparison Lead Acid to Lithium-Ion in Stationary Storage Applications, The Alternative Energy eMagazine, AllCell Technologies, 2012.

[11] D. A. G. Redpath, D. McIlveen-Wright, T. Kattakayam, N. J. Hewitt, J. Karlowski, and U. Bardi, "Battery powered electric vehicles charged via solar photovoltaic arrays developed for light agricultural duties in remote hilly areas in the Southern Mediterranean region," Journal of Cleaner Production, vol. 19, no. 17-18, pp. 2034-2048, 2011.

[12] S. M. Shaahid and I. El-Amin, "Techno-economic evaluation of off-grid hybrid photovoltaic-diesel-battery power systems for rural electrification in Saudi Arabia-a way forward for sustainable development," Renewable \& Sustainable Energy Reviews, vol. 13, no. 3, pp. 625-633, 2009.

[13] W. Brown and D. C. Brusless, "Motor control made easy," Microchip Technology DS00857, 2002.

[14] G. Walker, "Evaluating MPPT converter topologies using a matlab PV model," Journal of Electrical \& Electronics Engineering, vol. 21, no. 1, pp. 49-55, 2001.

[15] E. Lorenzo, Electricity Engineering of Photovoltaic Systems, Artes Graficas Gala, Madrid, Spain, 1994.

[16] J. A. Gow and C. D. Manning, "Development of a photovoltaic array model for use in power-electronics simulation studies," IEE Proceedings: Electric Power Applications, vol. 146, no. 2, pp. 193-200, 1999.
[17] F. M. González-Longatt, Model of Photovoltaic Module in Matlab, 2do Congreso Iberoamericano de Estudiantes de Ingeniería Eléctrıca, Electrónıca Computación, II Cibelec, 2005. 

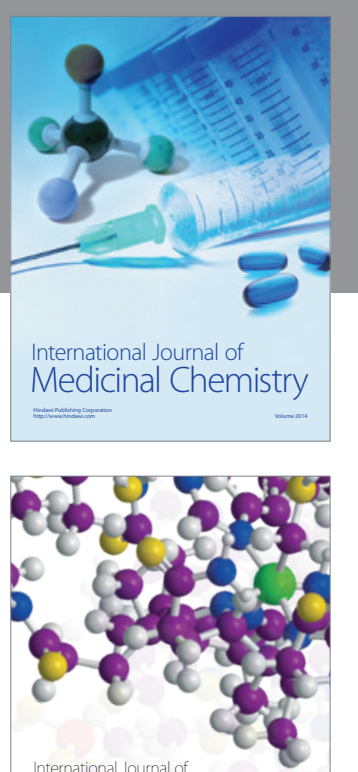

Carbohydrate Chemistry

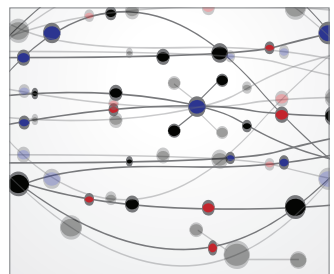

The Scientific World Journal
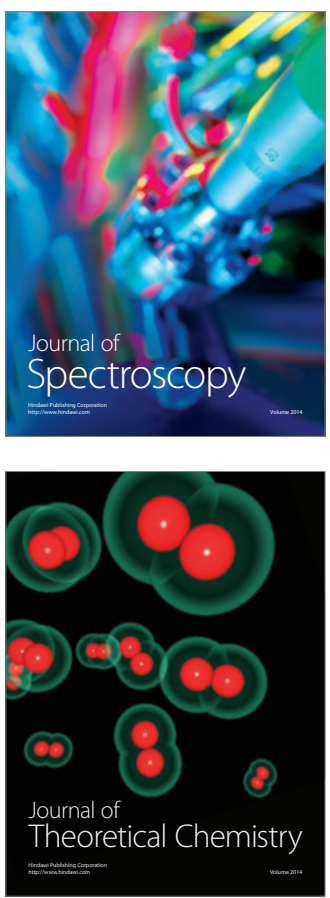
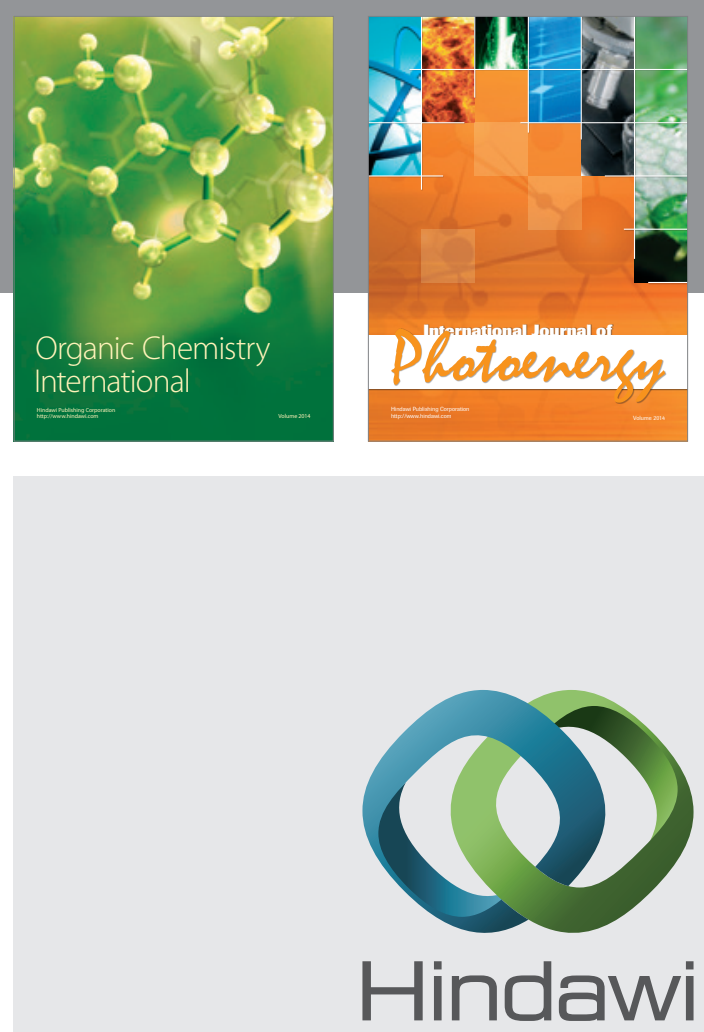

Submit your manuscripts at

http://www.hindawi.com

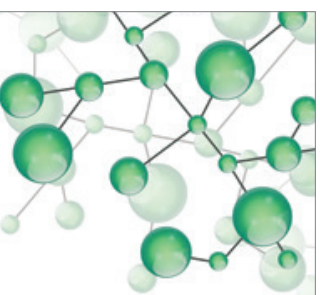

International Journal of

Inorganic Chemistry

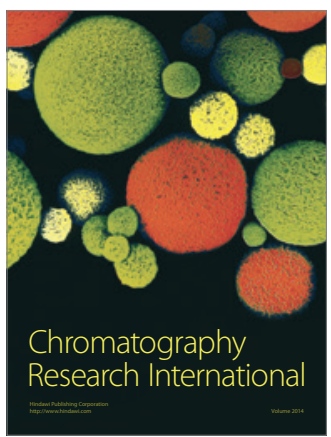

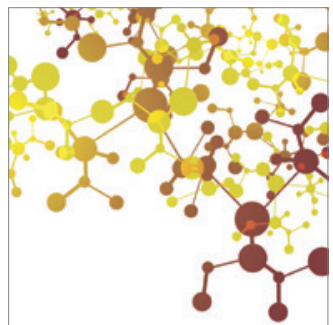

Applied Chemistry
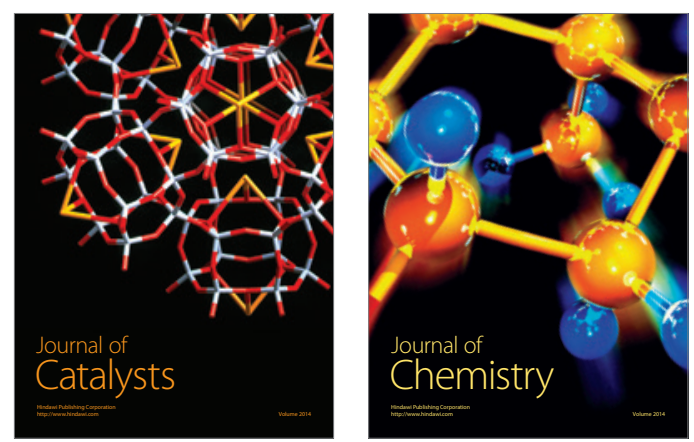
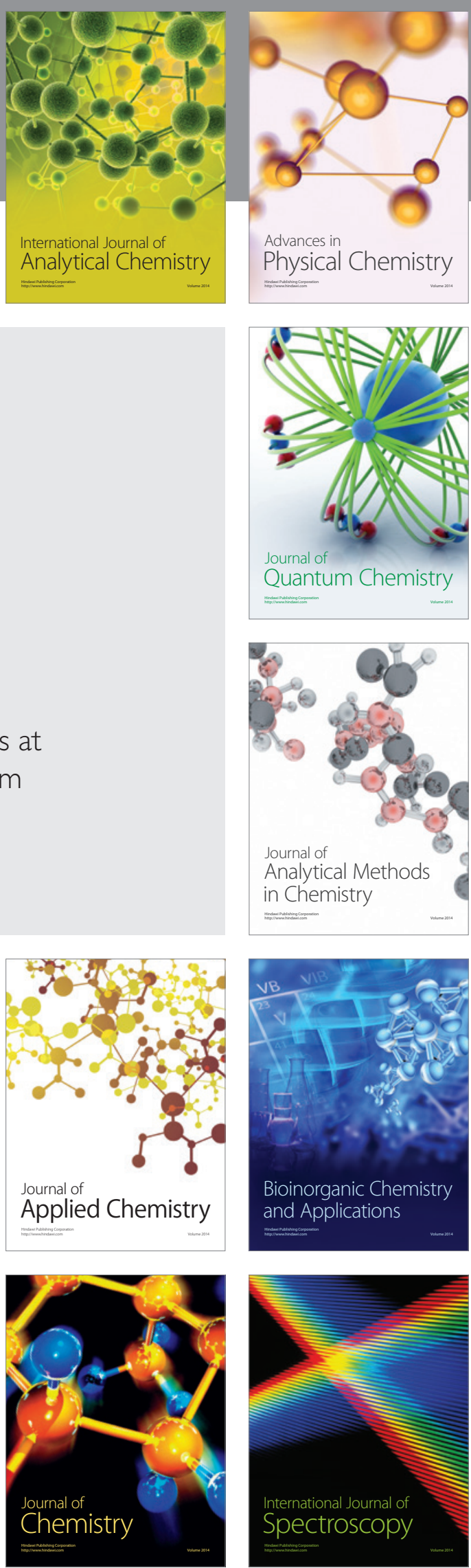